Original Research Paper

\title{
Impact of Drinking Water Treatment on Poultry Health and Performances: An Experimental Study
}

\author{
${ }^{1}$ Cherifa Boumedous, ${ }^{2,3}$ Zouhir Djerrou and ${ }^{3}$ Youcef Hamdi Pacha \\ ${ }^{I}$ Department of Biological Sciences, Faculty of Sciences, University of Oum Bouaghi, Algeria \\ ${ }^{2}$ Department of Sciences of Nature and Life, Faculty of Sciences, University of August 20th 1955, Skikda, Algeria \\ ${ }^{3}$ Laboratory of Pharmacology and Toxicology, University of Mentouri Constantine 1, Algeria
}

Article history

Received: 31-12-2016

Revised: 03-02-2017

Accepted: 04-02-2017

Corresponding Author:

Youcef Hamdi Pacha

Laboratory of Pharmacology and

Toxicology, University of

Mentouri Constantine 1, Algeria

Email: hamdpacha@yahoo.fr

\begin{abstract}
The present study aimed to investigate the impact of water quality on broilers performance. Two flocks of 10 chicks each were separated and maintained in the same poultry barn in Hamma Bouziane (Constantine). The animals were given standard food in the same husbandry conditions. The first group was provided untreated well water; however, the second one was given water treated by sodium hypochlorite. The water was analyzed for physicochemical and bacteriological characteristics at days 0 and 42 in the two flocks. The growth of chicks was investigated each week until 42th day. The results obtained has revealed that water untreated was contaminated and does not meet the standards recommended by WHO, it led to a decrease in performance represented by a very significant decrease in weight from the 7th to the 42nd day. The study demonstrates the importance of drinking water treatment in the success of broiler breeding.
\end{abstract}

Keywords: Physicochemical Water Parameters, Chlorination, Broilers, Antibacterial Treatments, Performance

\section{Introduction}

Water is the most important nutrient for poultry; birds generally drink approximately twice as much water as the amount of feed consumed on a weight basis (Blake and Hess, 2001). When temperature is high, water consumption is three times increased and water quality has emerged as one of the factors explaining water use, episodes of diarrhea but also the criterion on which a large margin of progress is possible (Travel et al., 2006). Animals that cannot drink properly (insufficient quantity and quality of water) will tend to eat less, therefore grow less quickly and thus be less productive.

In poultry farms, digestive pathologies are more and more difficult to control by breeders. These digestive disorders, especially enteropathies, as well as an enteritis will cause moistening of the droppings, this degrades the state of the litter which becomes difficult to manage and which leads to an ammonia production which irritates the respiratory system; it is then easy to be wrong of target when treating a respiratory disease! Thus, litter degradation can be related to digestive disorders before 42 day (diarrhea or nonspecific enteritis) whose agents can be infectious agents. Indeed, there is a relationship between the technical performances and the management of the watering by the breeder, animals has to develop pathologies that will have an economic impact. In the case of a microbial or viral infection, the intestinal wall may be affected as a result of digestive disorders, which mainly result in enteritis (Hoerr, 1988). These pathologies generally result in increased secretion of water and electrolytes and inflammation in the intestinal mucosa causing excretion in the litter of undigested food fractions. These profuse diarrheas moisten litter (Ruff et al., 1981; Hoerr, 1988). A degraded litter favors the development of coccidia which can be the cause of a decrease in live weight in the adult and a decrease in growth in the young. Also, deteriorated litter has a direct impact on the locomotor system of animals (lameness, sternum ulcers) with an impact on carcass quality (increase in seizure rate, decrease in yield, lesions of the breast). So the first point to consider is the impact of the bacteriological and physico-chemical quality of water on poultry farming, the use of pipettes limits this risk, but does not solve upstream chemical and microbiological pollution. The presence of micro-organisms in water is caused by the contamination of wells and springs by fecal matter (presence of enterococcal fecal streptococci) or by fouling of distribution networks, which then become privileged places of multiplication bacterial growth (Guérin et al., 2011). The second point is to ensure a high level of protection for humans. Contaminated livestock can also contaminate other 
farms, but also humans directly or the food they consume (Montiel, 2007).

The third point is the application of a mandatory disinfectant that is indispensable and obligatory to remove bio-residual bacterial films not eliminated by stripping and to prevent the reconstitution of a bio-film, especially Salmonella, from residual bacteria (Itavi, 2004).

The current study aims to investigate the impact of the bacteriological and physico-chemical quality of water on broiler chicken performances.

\section{Materials and Methods}

\section{Experimental Protocol}

This study was conducted on two lots of broiler chickens of 10 each, which were monitored weekly, from day 1 to 42 days. The two lots are placed in the same building, separated and under a common environment and with administration of the same foods for both lots in quantity and duration. The chicks were controlled at days: 1, 7, 14, 21, 28, 35 and 42, the weight was recorded each visit. The source of water supply was different for the two batches: A batch of 10 animals was supplied untreated well water; the second batch (10 animals) was supplied with treated and controlled water obtained from public water supply network system (circuit water). Complete bacteriological analyzes were carried out to ascertain the quality of the water at the inlet and the outlet of the pipes at the level of the breeding vessel and at the last drinking trough, with a partial bacteriological analysis at the end of the line. The samples of water were collected in dark sterile glass bottles of 250 and $1000 \mathrm{~mL}$, which were transferred at $4^{\circ} \mathrm{C}$ to microbiological laboratory of Dakssi (Constantine) (Papadopouloua et al., 2008). The bacteriological quality of water was performed by the membrane filter technique as described in Standard Methods (APHA, 1998) to investigate the following parameters: Total flora, Total Coliforms (TC), coliforms TT, Faecal Streptococci (FS), sulfite-reducing bacteria and Salmonella according to procedures described elsewhere (Papadopouloua et al., 2008).

Full and partial physico-chemical analyzes were also carried out (every 15 days). Day 1 analyzes at the building and at the last watering trough allows us to know the state of cleanliness of the pipelines, because knowing the content of micro-organisms determines the state and thickness of the bio-film, which serves as support for pathogens. The other bacteria sought are pathogenic and are a sign of contamination of water. The measurements of free chlorine and $\mathrm{pH}$ are carried out at each visit to the last feeding trough; to verify if the treatment products added at the level of the building end up (Travel et al., 2007), the water temperature was measured each visit by a thermometer at the drinking troughs.
In order to check the performance of the growing birds, an individual weighing was carried out for all the animals, every week, taking care to handle the subjects in calm (Traore, 2015).

\section{Statistical Analysis}

The results of animal weights were presented as mean with their variances. The data were analysis by one way Anova to compare the differences between the two groups; the level of significance was set at of $p \leq 0.05$.

\section{Results}

\section{Results of Physicochemical Analysis of Water}

As shown in Table 1, well water (supplied for flock 1) has higher nitrate and iron content than recommended standards as well as the $\mathrm{pH}$ and the hardness; these parameters are relatively high that standards mentioned in Table 2 (WHO, 1998).

For the second group, chicks were supplied with water coming from the public water distribution network, hence, normally the assurance of water of proper quality (Table 3). Thus the physicochemical analysis of tap water indicates that it is hard water. A continuous processing is performed on the water by sodium hypochlorite $(\mathrm{NaCl})$.

\section{Bacteriological Analysis Results}

In qualitative terms, the sanitary quality of the water is low because it does not meet the standards recommended by the WHO (1998). So, there is a biological pollution linked especially to fecal coliforms and fecal streptococcus, well water was not protected and no antibacterial treatment is introduced for improving its quality (Table 4).

For second flock (Table 5), we notice the presence of aerobic germs in tap water which corresponds to bacterial development suspended in pipes with organic matter, this total flora decreases from the 28th day, this decrease is visible only from the 42 nd day because of progressively injected and controlled chlorine.

In some cases of water rechlorination at much higher chlorine levels to those used for water intended for human consumption: 0.2 to $0.3 \mathrm{mg} \mathrm{L}^{-1}$ of chlorine for humans and 2 to $3 \mathrm{mg} \mathrm{L} \mathrm{L}^{-1}$ of chlorine for poultry, because birds are bacteriologically more sensitive, a good water quality is needed.

\section{Zootechnical Performances of Flocks}

By comparing the weight of the two flocks of broilers with different watering source (Table 6), one flock is watered by treated drinking water and the other flock is watered by untreated drinking water. A significant difference was found in weight between the two flocks 
with a better gain in weight for the flock whose source of water was treated. The results of physicochemical and bacteriological analyzes and the efficiency of the treatment of water with the reduction of bacterial load
(Total coliforms), disappearance of pathogenic bacteria, hence the disappearance of bio-film with the broilers weight increase, all these results suggest that treated water is a factor of a real broiler breeding success.

Table 1. Physicochemical analysis of well water (flock 1)

\begin{tabular}{|c|c|c|c|c|c|c|}
\hline \multirow[b]{3}{*}{ Date of sampling } & \multicolumn{3}{|c|}{ Complete physicochemical analysis } & \multicolumn{3}{|l|}{ Partial analysis } \\
\hline & $\begin{array}{l}\text { Well } \\
\text { water }\end{array}$ & $\begin{array}{l}\text { Circuit } \\
\text { water }\end{array}$ & $\begin{array}{l}\text { Water from } \\
\text { the trough }\end{array}$ & $\begin{array}{l}\text { Water from } \\
\text { the trough }\end{array}$ & $\begin{array}{l}\text { Water from } \\
\text { the trough }\end{array}$ & $\begin{array}{l}\text { Water from } \\
\text { the trough }\end{array}$ \\
\hline & 1st day & 1st day & 1st day & On the 14th day & On the 28 th day & On the 42 th day \\
\hline$\overline{\mathrm{PH}}$ & 7,7 & 8 & 8 & 8,5 & 8,5 & 8,5 \\
\hline Temperature & $19^{\circ} \mathrm{C}$ & $24^{\circ} \mathrm{C}$ & $27^{\circ} \mathrm{C}$ & $26^{\circ} \mathrm{C}$ & $28^{\circ} \mathrm{C}$ & $27^{\circ} \mathrm{C}$ \\
\hline Hardness & 72,5 & ND & ND & ND & ND & ND \\
\hline Nitrate (mg/l) & 80 & ND & ND & ND & ND & ND \\
\hline $\operatorname{Iron}(\mathrm{mg} / \mathrm{l})$ & 1 & ND & ND & ND & ND & ND \\
\hline
\end{tabular}

ND: Not detected

Table 2. Standards parameters of water for human consumption and for breeding (AFSSA, 2005)

\begin{tabular}{|c|c|c|c|c|c|c|}
\hline \multicolumn{2}{|c|}{ Standards parameters } & \multicolumn{2}{|c|}{ Potability for human } & \multicolumn{3}{|c|}{ Satisfactory water for breeding } \\
\hline \multicolumn{2}{|c|}{ Temperature * } & \multicolumn{2}{|c|}{$\leq 15^{\circ} \mathrm{C}$} & \multicolumn{2}{|l|}{$16^{\circ} \mathrm{C}$} & \\
\hline & \multirow{2}{*}{\multicolumn{2}{|c|}{$\begin{array}{l}6.5<\mathrm{pH}<8.5 \\
\text { Soft. } 8^{\circ} \mathrm{F}<\mathrm{HT}<15^{\circ} \mathrm{F}\end{array}$}} & \multicolumn{2}{|c|}{$6.5<\mathrm{pH}<7.5$} & \\
\hline & Hardness $(\mathrm{HT})^{* *}$ & & & \multicolumn{2}{|c|}{10 to $15^{\circ} \mathrm{F}$} & \\
\hline \multicolumn{2}{|l|}{ Nitrate } & \multicolumn{2}{|c|}{$\begin{array}{l}\text { Hard: } 15^{\circ} \mathrm{F} \leq \mathrm{HT}<30^{\circ} \mathrm{F} \\
<50 \mathrm{mg} \mathrm{L}^{-1}\end{array}$} & \multirow{2}{*}{\multicolumn{3}{|c|}{$\begin{array}{l}50 \mathrm{mg} \mathrm{L}^{-1}+\text { with a margin up to } 80 \mathrm{mg} \mathrm{L}^{-1} \\
\text { (if the water is bacteriologically appropriate) }\end{array}$}} \\
\hline & & \multicolumn{2}{|c|}{$<0.2 \mathrm{mg} \mathrm{L}^{-1}$} & & & \\
\hline \multicolumn{7}{|c|}{$\begin{array}{l}* \text { For reasons of organoleptic quality, maintain drinking wa } \\
\text { Hardness was given in degrees French }\left({ }^{\circ} \mathrm{F}\right)\end{array}$} \\
\hline \multirow[b]{3}{*}{ Date of sampling } & \multicolumn{6}{|c|}{ Complete physicochemical analysisPartial physicochemical analysis } \\
\hline & $\begin{array}{l}\text { Public } \\
\text { water }\end{array}$ & $\begin{array}{l}\text { Circuit } \\
\text { water }\end{array}$ & $\begin{array}{l}\text { Water from } \\
\text { the trough }\end{array}$ & $\begin{array}{l}\text { Water from } \\
\text { the trough }\end{array}$ & $\begin{array}{l}\text { Water from } \\
\text { the trough }\end{array}$ & $\begin{array}{l}\text { Water from } \\
\text { the trough }\end{array}$ \\
\hline & 1st day & 1 st day & 1st day & 14th day & 28th day & 42th day \\
\hline$\overline{\mathrm{PH}}$ & 7,1 & 7 & 6,5 & 6,7 & 6,7 & 6,9 \\
\hline Temperature & $25^{\circ} \mathrm{C}$ & $26^{\circ} \mathrm{C}$ & $24^{\circ} \mathrm{C}$ & $25^{\circ} \mathrm{C}$ & $25^{\circ} \mathrm{C}$ & $21^{\circ} \mathrm{C}$ \\
\hline Hardness & 42 & ND & ND & ND & ND & ND \\
\hline Nitrate $(\mathrm{mg} / \mathrm{l})$ & 50 & ND & ND & ND & ND & ND \\
\hline $\operatorname{Iron}(\mathrm{mg} / \mathrm{l})$ & 0 & ND & ND & ND & ND & ND \\
\hline
\end{tabular}

ND: Not detected

Table 4. Bacteriological analysis of collected water (flock 1)*

\begin{tabular}{|c|c|c|c|c|c|c|c|}
\hline \multirow[b]{2}{*}{ Date of sampling } & \multicolumn{3}{|c|}{ Complete physicochemical analysis } & \multicolumn{3}{|c|}{ Partial bacteriological analysis } & \multirow{2}{*}{$\begin{array}{l}\text { Bacteriological } \\
\text { standards } \\
\text { recommended } \\
\text { in poultry farming } \\
\text { (Itavi, 2001; } \\
\text { Villate, 2001) }\end{array}$} \\
\hline & $\begin{array}{l}\text { Well } \\
\text { water } \\
\text { 1st day }\end{array}$ & $\begin{array}{l}\text { Circuit } \\
\text { water } \\
1 \text { st day }\end{array}$ & $\begin{array}{l}\text { Water from } \\
\text { the trough } \\
\text { 1st day }\end{array}$ & $\begin{array}{l}\text { Water from } \\
\text { the trough } \\
14 \text { th day }\end{array}$ & $\begin{array}{l}\text { Water from } \\
\text { the trough } \\
28 \text { th day }\end{array}$ & $\begin{array}{l}\text { Water from } \\
\text { the trough } \\
42 \text { th day }\end{array}$ & \\
\hline Total flora & 300 & 600 & 600 & 800 & 800 & 800 & $<100$ (in $100 \mathrm{~mL}$ ) \\
\hline Total coliforms & 500 & 1100 & 1100 & 1100 & 1100 & 1100 & $<5($ in $100 \mathrm{~mL})$ \\
\hline Coliformes TT & 0 & 13 & 13 & 16 & 16 & 16 & $<5($ in $100 \mathrm{~mL})$ \\
\hline Fecal streptococci & 6 & 6 & $<10$ & $<10$ & $<10$ & $<10$ & $<5($ in $100 \mathrm{~mL})$ \\
\hline $\begin{array}{l}\text { Sulphite-reducing } \\
\text { bacteria }\end{array}$ & absence & absence & absence & absence & absence & absence & $<2($ in $20 \mathrm{~mL})$ \\
\hline Salmonella & absence & absence & absence & absence & absence & absence & 0 in 51 \\
\hline Water treatment & No treatment & No treatment & No treatment & No treatment & No treatment & No treatment & \\
\hline
\end{tabular}

*Group of chicks supplied with untreated water 
Table 5. Bacteriological analysis of collected water (flock 2)*

\begin{tabular}{|c|c|c|c|c|c|c|c|}
\hline \multirow[b]{2}{*}{ Date of sampling } & \multicolumn{3}{|c|}{ Complete physicochemical analysis } & \multicolumn{3}{|c|}{ Partial bacteriological analysis } & \multirow{2}{*}{$\begin{array}{l}\text { Bacteriological } \\
\text { standards } \\
\text { recommended } \\
\text { in poultry farming } \\
\text { (Itavi, 2001; } \\
\text { Villate, 2001) }\end{array}$} \\
\hline & $\begin{array}{l}\text { Public } \\
\text { water } \\
\text { 1st day }\end{array}$ & $\begin{array}{l}\text { Circuit } \\
\text { water } \\
1 \text { st day }\end{array}$ & $\begin{array}{l}\text { Water from } \\
\text { the trough } \\
1 \text { st day }\end{array}$ & $\begin{array}{l}\text { Water from } \\
\text { the trough } \\
14 \text { th day }\end{array}$ & $\begin{array}{l}\text { Water from } \\
\text { the trough } \\
28 \text { th day }\end{array}$ & $\begin{array}{l}\text { Water from } \\
\text { the trough } \\
\text { 42th day }\end{array}$ & \\
\hline Total flora & 30 & 300 & 300 & 300 & 100 & $<3$ & $<100$ (in $100 \mathrm{~mL}$ ) \\
\hline Total coliforms & absence & absence & absence & absence & absence & absence & $<5$ (in $100 \mathrm{~mL})$ \\
\hline Coliformes TT & absence & absence & absence & absence & absence & absence & $<5($ in $100 \mathrm{~mL})$ \\
\hline Faecal streptococcus & absence & absence & absence & absence & absence & absence & $<5($ in $100 \mathrm{~mL})$ \\
\hline Sulphite-reducing bacteria & absence & absence & absence & absence & absence & absence & $<2($ in $20 \mathrm{~mL})$ \\
\hline Salmonella & absence & absence & absence & absence & absence & absence & 0 in 51 \\
\hline Water treatment & 0 & 0 & 0.3 & 0.2 & 0.2 & 0.2 & \\
\hline
\end{tabular}

*Experimental group (water treated by sodium hypochlorite)

Table 6. Weights of broilers of the two groups during 6 weeks

\begin{tabular}{|c|c|c|c|c|c|}
\hline \multirow[b]{2}{*}{ Age (day) } & \multicolumn{2}{|c|}{ Weight (g) (flock 1) untreated water } & \multicolumn{2}{|c|}{ Weight (g) (flock 2) treated water } & \multirow{2}{*}{$\begin{array}{l}\text { Flock } 1 \text { Vs flock } 2 \\
\text { Pvalue }\end{array}$} \\
\hline & Mean & Variance & Mean & Variance & \\
\hline 1 & 58 & 4,444 & 57,5 & 6,944 & 0,64504 \\
\hline 7 & 109 & 8,88 & 155,55 & 27,777 & $1,46549 \mathrm{E}^{-14}$ \\
\hline 14 & 211,55 & 39,527 & 405,111 & 28,861 & 0 \\
\hline 21 & 408,5 & 4,285 & 605,22 & 22,694 & 0 \\
\hline 28 & 709 & 7,142 & 811,111 & 111,111 & $4,996 \mathrm{E}^{-14}$ \\
\hline 35 & 1008,5 & 4,285 & 1112,44 & 94,027 & $9,99201 \mathrm{E}^{-15}$ \\
\hline 42 & 1299,75 & 16,5 & 1412,444 & 94,777 & $6,88338 \mathrm{E}^{-15}$ \\
\hline
\end{tabular}

\section{Discussion}

\section{Physico-Chemical Quality of well Water and Mains Water}

The temperature of the water is between 19 and $28^{\circ} \mathrm{C}$; these high temperatures can be explained by the influence of the ambient temperature on the water, but also the underground water table, itself being at a shallow depth. It should be noted that water with a temperature between 25 and $28^{\circ} \mathrm{C}$ is a good culture medium for environmental microorganisms (Makoutode et al., 1999). For Vaillant (1973), a temperature of $25^{\circ} \mathrm{C}$ favors the metabolism of mesophilic species. A high water temperature in the network of $18^{\circ} \mathrm{C}$ or water tarps can be the basis of a major planktonic development (Bouziani, 2000). It should be mentioned that the use of fresh water to combat heat stress can have a positive effect; studies have shown that giving fresh water to chickens contributes to their daily weight gain (Olkowski, 2009). It is also pointed out that the lowering of the temperature below the norms lead to a slowing down of the molecular agitation and a less dispersion of the chlorine molecules (Bouziani, 2000).

The results of analyzes show that well water and mains water have a high hardness, this high hardness is generally due to an excess of calcium, magnesium, manganese and iron (Itavi, 2001). Our water has a hardness of more than $15^{\circ} \mathrm{F}$ as recommended by the WHO (WHO, 1998), it significantly increases the total flora concentration at start-up and the risk of contamination by germs and this is consistent with our results and results found the study of Travel et al. (2006).

The very calcareous waters can easily lead to a scaling of the pipes (Keck, 1995), accidents of breeding, precipitation of salts in the watering equipment, which can decrease the flow of water and potential water deprivation. Water deprivation has adverse effects on poultry growth rates with increased morbidity and mortality and may disrupt antibacterial treatment (Itavi, 2004; Olkowski, 2009).

The $\mathrm{pH}$ is an indicator on the acidity or basicity of water, the water of the present study has a basic $\mathrm{pH}$; it is water calcareous or soiled by organic matter, this has been demonstrated by Keck (1995).

At day 0 , a $\mathrm{pH}$ greater than 6 promotes the development of the bio-film in the pipes upstream of the building and in the building. At day 30, a PH higher than 7 significantly increases the risk of contamination of drinking water by potentially pathogenic bacteria, which has been demonstrated in our analyzes. However, $\mathrm{pH}$ is probably the most important factor to consider when assessing water quality. Our results are consistent with those obtained by Travel et al. (2006).

It should be emphasized that a water rich in organic matter and iron would promote the progression of the bacterial load, the presence of organic matter in the drinking troughs and in the pipes is common and associated with a high temperature will promote the development of fecal germs such as Streptococci and coliforms and Salmonella 
(Itavi, 2004), in fact the formation of bio-film in pipelines can relegate bacteria that will contaminate water (Pupin et al., 2013), without forgetting the neutralization of the treatment applied (Itavi, 2006).

The chemical results of water collected during our study reveal the presence of chemical elements, pollution index such as nitrates and iron; nitrates are an indicator of organic or fecal pollution (Villate, 2001). High concentrations of nitrate are generally due to contamination, non-leakage of wells, permeable soils with deep water table, located in intensive farming areas or in infiltration sites of septic tanks. A recent study by Zaki et al. (2004) found that the presence of nitrate in drinking water can alter the functions of thyroid hormones, which can have a negative impact on growth rate. As a result, high nitrate levels may cause digestive problems and low growth.

\section{Bacteriological Quality of Water}

Bacteriological analysis has shown that well water is more contaminated than network water and shows bacteriological pollution related mainly to total coliforms, fecal coliforms and fecal streptococci. The presence of these contamination germs may be due to a failure of disinfection, contamination of the reservoir, work on the network (Joffin and Joffin, 1999). This pollution increases greatly in drinking troughs or the formation of a bio-film. The behavior of the breeders (the non respect of the rules of hygiene), the factors related to the mode of water management (collection, transport, storage). Analysis of total coliforms provides information on the health quality of water and the possible vulnerability of a source to surface pollution and are essential in the diagnosis of fecal contamination (Rodier et al., 2009). Therefore, the main source of water supply to the building is a risk factor for the initial contamination of water by the indicator flora (potentially pathogenic germs). The wells vehicles more germs than the public grid.

\section{Treatment with Sodium Hypochlorite}

The bacteriological analyzes carried out show the effectiveness of the treatment; at 35 and 42 days, the presence of the flora indicator is significantly reduced with antibacterial treatment. Permanent chlorination makes it possible to reduce the development of the total flora to the last watering place at 35 and 42 days. Compliance with these recommendations for the presence of a buffer tank, a product/water contact time of $20 \mathrm{~min}$ and control of the residual doses up to the last watering point, can destroy $100 \%$ of the germs present in the water. Compliance with these recommendations for efficient chlorination and regular control at the end of the line is associated with a reduced contamination of the pipelines by the bio-film at 35th day (Leclerc et al.,
1977; Leclerc and Mossel, 1989). The bacteriological treatment significantly reduces the risk of water contamination, early disinfection $(<2$ weeks of chicken age) or in case of diarrhea, reduces the risk of water contamination at the last watering place on day 35 according to Travel et al. ( 2007) and this was demonstrated in our study.

It should be noted that the presence of fecal streptococci in the livestock building and in the drinking troughs at start-up is mainly due to the storage conditions that are involved. Tank and circuit and reservoir water, in the case of untreated water and even more with chlorinated water in which the level of free chlorine has disappeared completely, the stagnation of water in the reservoirs causing dramatic increases in total bacteria ranging from 10 to 10,000 times that initial number, this disturbance may further affect the enumeration at $20^{\circ} \mathrm{C}$. In water distributed in networks, the microorganisms tend to deposit and then to attach themselves to the pipes constituting a bio-film (Haslay and Leclerc, 1993). Our bacteriological results are closed to the results of the study obtained by Itavi (2006). The type of material constituting the pipes, before the building and between the building and the drinkers, influences the proportion of total flora present at start-up. The polyethylene of high density constituting the pipes going from the building to the drinkers decreases the amount of bio-film found at start up to the beak of the bird will always be less than $1000 \mathrm{CFU} / 100 \mathrm{~mL}$.

The filter placed before the treatments, its change and its regular washing, reduce the risk of contamination by germs at the end of the line at 35 th day thus reducing the presence of the bio-film in the pipes. The early appearance of diarrhea (as of the 10th day of age) for the first batch (untreated water) suggests that the presence of bio-film in the pipes at start-up is a factor favoring the appearance of digestive disorder from the first days. This was proved in our study.

\section{Conclusion}

The quality of drinking water is an important factor that may increase the transmission of pathogenic germs to animals. In some cases, water can cause substantial mortalities in intensive farming, to the point where rechlorination of tap water is even crucial. The microbiological quality of drinking water should be supervised by analysis and regular controls to ensure its safety.

Deterioration in performance at the beginning as well as heavy economic losses caused by the degree of digestive disorders, require the respect of good hygienic practices during the breeding period, this can keep the barn clean of germs, prevent the endangerment of the broilers' health status and reduce digestive imbalances. 


\section{Acknowledgement}

We would like to thank all the persons who helped us to carry out this work in its different stages.

\section{Funding Information}

No necessary funding information.

\section{Author's Contributions}

Cherifa Boumedous: The first author designed the study, assisted sample collection, data analysis and manuscript preparation.

Zouhir Djerrou: Participated in manuscript preparation and results discussion.

Youcef Hamdi Pacha: Designed and supervised the study and participated in results interpretation.

\section{Ethics}

This article is original and contains unpublished material. The corresponding author confirms that no ethical issues involved.

\section{References}

AFSSA, 2005. French food safety agency. 3rd legislature of 01.01.2006.

APHA, 1998. Microbiological Examination, Part 9000. In: Standard Methods for the Examination of Water and Wastewater, Clesceri, L.S., A.E. Greenberg and A.D. Eaton (Eds.), American Public Health Association, Washington, ISBN-10: 0875532357, pp: 1220.

Blake, J.P. and J.B. Hess, 2001. Evaluating water quality for poultry. ANR.

Bouziani, M., 2000. Notion de la potabilité de l'eau: l'eau de la pénurie aux maladies.

Guérin, J.L., D. Balloy and D. Villate, 2011. Poultry diseases.

Haslay, C. and H. Leclerc, 1993. Micribiology of drinking-water. In: Microbiologie Des Eaux D'alimentation, Haslay, C. and H. Leclerc (Edn.), Tec \& Doc-Lavoisier, Paris, ISBN-10: 2852069180, pp: 495.

Hoerr, F.J., 1988. Pathogenesis of enteric diseases. Poultry Sci., 77: 1150-1555. PMID: 9706081

Itavi, 2001. The quality of water has direct impact on poultry health. Sci. Technical Rev.

Itavi, 2004. Water in poultry farms. Poultry Sci. Technol., 1086: 10-11.

Itavi, 2006. Poultry raising and digestive disease of turkey chick. Edition Science and Technology in Animal Products.

Joffin, C. and N.J. Joffin, 1999. The Waters: In microbiology alimentary.

Keck, G., 1995. Quality of breeding water and hygienic of the food chain. Vet. Rev., 146: 815-820.
Leclerc, H. and D.A.H. Mossel, 1989. The main processing steps. Techniques documentationsLavoisier Paris.

Leclerc, H., R. Buttiaux, J. Guillaume and P. Watter, 1977. Disinfection of water.

Makoutode, M., A.K. Assani, E.M. Ouendo, V.D. Agueh and P. Diallo, 1999. Qualité et mode de gestion de l'eau de puits en milieu rural au Benin: Cas de la sous-préfecture de Grand-Popo. Médecine d'Afrique Noire, 46: 528-534.

Montiel, A., 2007. The quality of water in poultry.

Olkowski, A.A., 2009. La qualité de l'eau d'abreuvement du bétail: Guide de terrain relatif aux bovins, aux chevaux, à la volaille et aux porcs.

Pangborn, R.M. and L.I. Bertolero, 1972. Influence of temperature on taste intensity and degree of liking of drinking water. J. Am. Water Works Assoc., 64: 511-515.

Papadopouloua, C., V. Economoua, H. Sakkasa, P. Gousiaa and X. Giannakopoulosc et al., 2008. Microbiological quality of indoor and outdoor swimming pools in Greece: Investigation of the antibiotic resistance of the bacterial isolates. Int. J. Hyg. Environ. Health, 211: 385-397. PMID: 17728184

Pupin, P., J. Leorat and A. Dronneau, 2013. Qualité de l'eau. La lettre Synthèse élevage.

Rodier, J., B. Legube, N. Merlet and R. Brunet, 2009. L'analyse de l'eau. Eaux naturelles, eaux résiduaires, eau de mer, 9e éd. Technique et ingénierie, Dunod, Paris.

Ruff, M.D., P.C. Augustine and P.A. Madden, 1981. Eimeria meleagrimitis, E. adenoeides and E. dispersa: Severity of infection and changes in the intestinal mucosa of the turkey. Exp Parasitol., 51, 1: 87-94.

Traore, A.O., 2015. Guide technique et économique d'un élevage de poulets de chair. Harmattan Mali.

Travel, A., I. Bouvarel, D. Chevalier, L. Fulbert and S. Garnier, 2006. Conduite d'élevage et pathologies digestives des dindonneaux-Quels facteurs maîtriser pour limiter l'impact des entérites non spécifiques? Étude de cas. Rapport OFIVAL.

Travel, A., D. Chevalier, F. Merlet and L. Fulbert, 2007. Facteurs de variation de la qualité bactériologique de l'eau en élevage de dindes. Septièmes Journées de la Recherche Avicole, Tours, 28: 537-540.

Vaillant, J.R., 1973. Protection de la qualité des eaux et maîtrise de la pollution.

Villate, D., 2001. Maladies Des Volailles. 3rd Edn., France Agricole, Paris, ISBN-10: 2855574668, pp: 576.

WHO, 1998. European standard for drinking water. World Health Organization.

Zaki, A., A. Ait Chaoui, A. Talibi, A.F. Derouiche and T. Aboussaouira et al., 2004. Impact of nitrate intake in drinking water on the thyroid gland activity in mal rat. Toxicol. Lett., 147: 27-33. 